\title{
'It Does Not Die' - Urban Protest in Kolkata,
} 1987-2007

An interview with Ranabir Samaddar

\section{Ramaswamy}

\section{(2) OpenEdition}

\section{Journals}

Electronic version

URL: http://journals.openedition.org/samaj/3230

DOI: $10.4000 /$ samaj.3230

ISSN: 1960-6060

Publisher

Association pour la recherche sur l'Asie du Sud (ARAS)

Electronic reference

V. Ramaswamy, "'It Does Not Die' - Urban Protest in Kolkata, 1987-2007 », South Asia Multidisciplinary Academic Journal [Online], 5 | 2011, Online since 30 December 2011, connection on 30 April 2019

URL : http://journals.openedition.org/samaj/3230 ; DOI : 10.4000/samaj.3230

This text was automatically generated on 30 April 2019.

\section{cc) (1) $\odot$}

This work is licensed under a Creative Commons Attribution-NonCommercial-NoDerivatives 4.0 International License. 


\title{
'It Does Not Die' - Urban Protest in Kolkata, 1987-2007
}

\author{
An interview with Ranabir Samaddar
}

\section{Ramaswamy}

\section{About Ranabir Samaddar}

1 Ranabir Samaddar is a leading political scientist of India, and founder of the Calcutta Research Group and its journal Refugee Watch. He is known for his critical studies on contemporary issues of justice, human rights, and popular democracy in South Asia, in the context of post-colonial nationalism, trans-border migration, community history, and technological restructuring. His recent books include The Emergence of the Political Subject and The Materiality of Politics.

2 Samaddar grew up in a family of communist associations. As a student in Kolkata during the turbulent 1960s, Samaddar was closely involved in the radical political activism of that time, which culminated in his incarceration. After his release under the amnesty for political prisoners, he completed his studies and worked as a college lecturer. He also devoted himself to exploring a new political practice in the prevailing scenario of West Bengal. During the 1980s, he was a founding member of a workers' solidarity platform in Kolkata, which was active in uniting former radical political activists in public action and communication. Among the initiatives of the platform was the building of a squatters' movement in Kolkata to press for a halt to evictions and for substantive resettlement. Samaddar was also the Co-convenor of the No More Bhopal Committee, a voluntary forum established in the wake of the Bhopal gas disaster in 1984. Together with workers and trade unions, the Committee spearheaded public activism and action-research in Kolkata on issues like occupational health and safety.

In the late-1980s and early-1990s, Samaddar studied the political economy of emerging technological restructuring in India and globally. He was a Fellow in the Centre for Studies in Social Sciences, Kolkata during 1989-92, and was subsequently attached to the Maulana Abul Kalam Azad Institute of Asian Studies. He was instrumental in setting up in 
1996 the Calcutta Research Group (CRG), a coming together of academics, activists, lawyers, trade unionists, journalists and women's rights activists. It was set up as a facilitating group in support of the peace movement in Kolkata, particularly the conference of the Pakistan-India People's Forum for Peace and Democracy. After a stint during 1999-2003 as the Director of the Peace Studies Programme at the South Asian Forum for Human Rights, Kathmandu, Samaddar returned to Kolkata to establish the CRG as a full-time, civil society led research and teaching institute, with a rights and justice orientation. He has been a close observer of the city of Kolkata, its plural society, politics, civic activism, and people's movements.

\section{The interview's context ${ }^{1}$}

4 A massive wave of protests erupted in Kolkata and West Bengal in late-2006, just a few months after an overwhelming electoral victory for the CPI(M)-led Left Front government of West Bengal. The protest was against land acquisition by the state in Singur, a fertile agricultural area, for transfer to Tata Motors for their car manufacturing plant. In early 2007, there was a conflagration of violence in connection with state plans for land acquisition in Nandigram for a chemical hub. Later in the year, violence erupted in rural areas across the state in protest against the malfunctioning public distribution system. The city of Kolkata was also an epicentre of protest agitations on all these issues, both by the principal opposition party, the Trinamool Congress (TMC), led by Ms Mamata Banerjee, as well as independent, left-leaning activists and intelligentsia. In November 2007, the city saw a major protest rally against the ruling CPI(M)'s violent actions in Nandigram by the intelligentsia and civil society. Later that month, violence suddenly erupted one morning in Kolkata, in protest against the residence in the city of the exiled Bangladeshi writer Tasleema Nasreen.

5 In the context of the uninterrupted rule and continuous electoral victories since 1977 by the Left Front, in a state where the intelligentsia and civil society had traditionally supported the left, 2007 marked a turning point.

6 Samaddar talks about the 'Mamata phenomenon'2 and analyses its development. This was remarkably prescient in the light of the subsequent unexpected electoral reverses suffered by the CPI(M) in the federal parliamentary elections in India in May 2009, in the municipal elections in West Bengal in May 2010, and finally in the state assembly elections in 2011. A once all-powerful party, with no political opposition, had been reduced to being merely a small opposition group in the state assembly.

7 The interview may be seen as a means to observe the political consciousness and way of thinking in a particular place, namely West Bengal, through the voice of a contemporary political thinker of the global south. Ranabir Samaddar is a Bengali, an identity and inheritance that one could see as defining him. As a student in the late-60s, Samaddar had been an active participant in the radical leftist upsurge in West Bengal, the Naxalite movement. ${ }^{3} \mathrm{He}$ is today a well-known political scientist and a prolific academic writer. Calcutta Research Group, established by him, is an important centre for critical studies in post-coloniality.

8 Samaddar points to the fact that it was Bengal that faced the first assault of colonial modernity. When he links this with Bengal being in the forefront of post-colonial resistance, rather than reading this as an expression of any chauvinism, one may see it as 
explicating a specificity: a local character, of fierce engagement and thinking on resistance, on politics, on alternatives, in a post-colonial situation, in the same place where, incidentally, colonial power and modernity had inevitably also given birth to its own resistance.

In retrospect, by the time this interview took place, a very major change had already taken place in the political environment of the state of West Bengal. The unassailable dominance of the Communist Party of India (Marxist), or CPI(M), had been badly shaken by a series of popular resistance and protest movements in the preceding two years, principally relating to land acquisition for private industry. In April 2008, Samaddar brought out an essay, 'Prescribed, Tolerated \& Forbidden Forms of Claim Making'. This was akin to a ring-side commentary on the outbreak of protest agitations in West Bengal from late 2006 through 2007. This was a period that marked the demise of the power commanded and wielded by the CPI(M). A critical indicator of the changed political environment had already been seen, namely the result of the panchayat or village council elections in mid-2008, in which several bastions of CPI(M) power were lost to the Trinamool Congress (TMC) led by Mamata Banerjee. The extent of the electoral reversal was limited, but it was an early indicator of what was to be an unstoppable and snowballing process of overturning of mass consciousness.

But at the time of this conversation, i.e. in October 2008, the general outlook was still more or less defined by the reality of West Bengal being akin to a single-party state, namely the CPI(M). The party's loss, and an electoral victory of the TMC, was as yet something inconceivable. Life in West Bengal meant being stuck with the CPI(M), like it or not. Yet the inconceivable happened, and the CPI(M)'s electoral defeat and subsequent marginalization from power has now become something mundane. This transformation of a political outcome, from the inconceivable to the mundane, merits some reflection upon. The conversation with Ranabir Samaddar helps one to better understand how the political transformation took place.

11 Ranabir Samaddar articulates a strand of thinking, in terms of which the unstoppable rise of Mamata Bannerjee can be seen and understood. He talks in terms of the political culture of a place, and its organic outcomes, he talks about feelings and memories, and shares his sense of the formation of political attitudes and ideas of action.

12 Samaddar is original, insightful and eloquent. But one could see his trajectory, from his student days, as representative of social and political movements that defined more than one generation in Bengal. His subsequent association with NGOs and then going on to establishing a think tank, while continuing to be critical of the CPI(M), is also representative of a wider socio-political stream in this place. It may also be seen as reflecting a continuing search by intellectuals here for a meaningful space and practice, towards an alternative, in changing times, within a context of long-term stagnation and economic blight and recent state attempts at neo-liberal economic policy.

\section{The interview}

\section{How would you describe Kolkata of the 1980s?}

Kolkata of the 1980s was not Calcutta of the 1960s. Although in the 1980s people tried to take up various actions in terms of protests, the nature of social and political protest had actually changed. By the mid-1980s, disillusionment with socialism and with China had 
set in. And in 1989 there was the collapse of the Berlin wall. The CPI(M) had hegemony over the state and the urban middle class. Urban radicals and erstwhile Naxalites were somewhat active, but fundamentally speaking, there was nothing of significance happening. Some of us radicals were trying to recreate the protest movements of the 1960s and early-1970s-with that same kind of radicalism of students and youth, the disregard for social strictures, an immense belief in human will, an uncompromising attitude to certain principles and the commitment to a dialogical process. But society was not suited to that. It felt fatigued and defeated. The revolutionary crust of society had been decimated.

There were also new aspirations now. Students did not want to study in Kolkata, there was an exodus to Delhi, the middle class wanted to send their children abroad for higher education. Thus one was faced with the first backlash of the defeats of the 1960s and 1970s.

The period in question can also be seen as one of decline of the CPI(M). They came to power in 1977 with a huge mandate, which was further strengthened in 1982. Even though they were involved with the atrocity in Marichjhapi in 1979, this did not really register in the public mind. ${ }^{4}$ The early 1980 s also saw the jute mill strike and the Gorkhaland agitation in North Bengal against Bengali sub-nationalism. The political landscape was polarized. There was the CPI(M), as the establishment, the discredited Congress in opposition, and the Naxalites, who were seen as adventure-seekers. But the latter had an instinctive appreciation of people's issues, a kind of 'populism' rather than 'intellectualism'. This was, however, quite different from the more recent brand of populism that we see with Mamata Banerjee. Besides, there were also independent and respected leftists or Marxists, like Biren Roy and Ajit Roy, who published the Marxist Review journal.

But Kolkata of the 1980s was a passive, dead city, materially and politically. Large numbers of factories were closed. Deindustrialization was real, with the largest number of factory closures being recorded in the 1980s. In the 1960s there were militant trade unions, and the student movement of that period must also be seen in the light of the militant labour movement. The Congress was not a party used to urban protest. Even in the period of the nationalist movement, it was only the radical section of the Congress which was involved in urban protests.

So, as an opposition force, it needed someone like Mamata, someone uncorrupted, to come out and find her feet in the political terrain. In the early 1990s, there were elections (parliament and state assembly), and there was the 14-party campaign against the Left Front government. A realization was dawning that the old style of protest was not possible any more. And of course, economic liberalization and globalization had begun and the aspirations of the middle class had begun to change.

Do you see anything 'unique' about Kolkata? And how do you view the massive changes that have visited Indian cities like Kolkata and Bombay over the last three decades?

Kolkata does have a unique streak of protest. It is an anarchic city, disdainful of the law. That can be understood too, for its having been the second city of the British Empire, and having endured famine, partition, deindustrialization, and the terrible anti-Naxalite violence of 1971, besides the whole intellectual tradition.

Pune had its upper caste, Brahmin intellectual tradition and ethos. It was the only city comparable to Kolkata in colonial times, in terms of high erudition, engagement with 
modernity and modern politics. Then there was Bombay, with its great tradition of working class movements. But ultimately that comes to a close with the trade union leader, Datta Samant, and into that vacuum the Shiv Sena steps in. ${ }^{5}$ Why did Bombay not go the way of Kolkata? That can't be explained simply in terms of Bombay being the financial capital. Bombay was a cosmopolitan city, not at all a provincial one. There was less of the petty bourgeoisie and more of the working class. But there was a huge transformation with the deindustrialization in the city. This overall transformation, with the role of technology, with the notion of sunset industries and sunrise industries, and restructuring taking place accordingly-the 1980s was the period when all this happened. Bombay did well in that process, with sectors like oil, oil exploration, financial services and real estate, although its earlier concentration of textile and engineering industries was now over.

But Calcutta lost out completely in this process of technology-induced restructuring and transformation. Bombay had a richer hinterland now, including Gujarat, with the latter's massive industrial growth based on the technological restructuring, as well as Karnataka and Kerala, the last with its linkage to inflows from the Gulf. The Bombay hinterland had a wide spread of industries. The IT sector was also beginning to come up. Bombay was now the most cosmopolitan centre. Though Kolkata also had a rich hinterland, was cosmopolitan, had a huge spread of industries, had industrial hubs like Durgapur, Rourkela and Bhilai in its hinterland, yet Kolkata died. The spirit of the city died by the 1980s. The 1960s saw the last cry of defiance of a city that was going down in any case.

\section{Can one talk about a 'defining feature' of Kolkata? Has this changed?}

21 A city like Kolkata definitely has a character of its own. There are networks, there is social capital, there is a particular pattern of education. Some things are learnt, one is taught to value and treasure certain things. There were clubs (youth associations in paras or neighbourhoods) where the youth spent their evenings. All great cities of the world show three or four key qualities. London, New York and Paris, for instance. A pride in the past. A robustness that endures. It is not just a question of amenities. The city must lend itself to the character of a collective. The city is a place of struggle, and a battle for resources. There are deep networks. Kolkata fits the bill in these terms.

The life of the city, the roots from which it drew strength, all these were drying up. Petty bourgeoisie education through state schools, the old-style schooling, the neighbourhood and community bonding, non-conformism, certain values-all were vanishing. With privatization of education or the disappearance of neighbourhood playgrounds, social dis-integration grew, a cognitive separation of classes.

With a process of transformation one should ask: what is transformed, and what remains? The attempt was to transform Calcutta into an orderly, well-regulated, well-policed, governed, predictable entity. The lawlessness and vitality were sought to be controlled. This used to be a city where anything could happen at any time. That was sought to be changed.

\section{What strikes you as the most significant change in Kolkata?}

There used to be no feeling of risk in Kolkata. That is changing. When someone says 'larke lenge...', ('we'll fight for it') it denotes a complete confidence, with no diffidence arising from any perception of risk or insecurity. This was the attitude of the rabble, a definite feature of Kolkata. That anyone has a right to do something. But this is something that causes difficulty to economists, banks, bourses, chambers of commerce and 
communication systems. They want the city to be a haven of trade and commerce, with free circulation of information and traffic of all kinds. Remember, Kolkata compelled even Robert McNamara, the President of the World Bank, to travel by helicopter from the airport to the city because of the massive protest demonstrations against him. Kolkata was a kind of primitive ground, of the attitude 'This is mine'. The government was there, but government control over the city was shaky in those days.

Risk is the shadow of security. No consciousness of security existed in the 1960s. There was no anxiety. They were simpler times, and life was simpler. When people have no consciousness of 'security', they can take risks. Social classes and groups in Kolkata were prone to a culture of protest. They were so prone to this because there was nothing called risk involved in doing that. The youth didn't have a sense of risk. Anything and everything was do-able, nothing was impossible. That was a distinct feature of Kolkata. All great cities of the world had this speciality, of provoking the imagination, prompting a sense of freedom, of desire for that.

Notwithstanding the deindustrialization and economic stagnation, do you see any positive feature in the 1980s and 1990s as far as Kolkata was concerned?

The 1980s and 1990s were decades of transition. It was a subdued period. The classic type of Kolkata protest underwent a change by the 1980s. The issues and the methods were different. The protest against squatter evictions in Baghbazar in early 1988, led by the Chhinnamul Sramajibi Adhikar Samiti (Organisation for the Rights of Uprooted Labouring People)-that could be called a classic one. There was wide-ranging participation, there were rallies as well as a hunger strike.

Voluntary organizations like Unnayan or Voluntary Health Association of India (VHAI) interacted and worked together with leftist political activists and groups. Not in the sense of providing money or funds, but active collaboration. After the Bhopal gas disaster, there was an enormous amount of activism. A considerable amount of mobilization was achieved, there were meetings and sit-in demonstrations. New issues also emerged, e.g. against automation, in support of peasant women in North Bengal or in support of subregional grievances in North Bengal, etc.

The most important event of this period was the 14-party campaign against the state government in the early 1990s. The issue of public transport and bus fares came to the forefront. That may be seen as a kind of link between the past and the present. For the first time since coming to power, the CPI(M) was on the back-foot. Following the protests led by Mamata Banerjee of the Congress in the early 1990s, thirteen supporters of Mamata were killed in police firing in Kolkata on 21 July 1993. In 1990 there had been a violent attack on Mamata Banerjee herself.

Another important event in Kolkata was the convention of the Pakistan-India People's Forum for Peace and Democracy in 1996. This was organized entirely by the civil society. Then we have globalization, with its effects coming to the fore around 2000. All the key, cutting-edge issues being articulated today, in this age of globalization, were actually given voice to in the 1980s and early 1990s.

One cannot be uncharitable to Calcutta of these two decades. During the 1940s, 1950s and 1960s, it was not just leftist protests. There were movements of subaltern people, or urban radicals, and there was a genuine desire for a better life. The Left used that underlying urge. In every radical society, after a change takes place, the new rulers' task is to stop unrest. Otherwise they would not be able to manage the transition to a new 
path, and to make the diversions necessary for this transition. The Soviet Union, China, Central Asia, all show this pattern. That iron grip over the society was what enabled the Soviet Union to prevail in the Second World War. Unruliness must be stopped. But of course, we had particularly bankrupt Bengali rulers, who simply did not know how to do this!

Kolkata represented a problem for all systems. After a period of massive unrest, and riding on a wave of popular discontent, the ruling party, the CPI(M), wanted to stymie the unrest in society. ${ }^{6}$ In the latter part of this period, this thrust is stronger, and yes it happens too, but does that mean the sinews and branches that sustain protest are wiped out?

We would do injustice to the 1990s if we said protest died out. It does not die. The autonomy of politics, of the city's own innate character ... to give credit to Kolkata, even after something like the anti-Naxalite massacres of the early 1970s, once the CPI(M) and the Left Front came in it took only about ten years for the spirit of the city to find its feet again. That expresses itself in the activism of Mamata. She could be called 'populist'. But populism is enormously important in the initial stages of the re-emergence of the restlessness of society. In a period of poverty of politics, of corruption, and degeneration of politics into protection-extortion, people's issues are articulated by voluntary activists. Mamata's populism may be seen as a fall-out of that. Mamata may be seen as the true child of the left project on the soil of Bengal.

Do you see any difference between Kolkata and, say, Delhi, for instance in terms of civil society organizations?

Another facet of Kolkata was that one did not see the emergence of big, 'corporate' NGOs, like PRIA or $\mathrm{CSE}^{7}$ of Delhi. Even Oxfam in Kolkata was not like that. People treated NGOs like the erstwhile civic associations. It was the lower middle class who were working in NGOs. They were not entrepreneurial. In the specific situation of Calcutta, NGOs did not go the way of their counterparts in Delhi. Here there was a notion that whatever is done has to relate to the public, that the public must be with you, that is to say even the unruly fellows on the street. There were people who acted as conscience-keepers, with their taunts about 'but what do the people say?' Thus organizations like Unnayan ${ }^{8}$ or VHAI also helped in the revival of social protest. They provided radicals a place to assemble and some support for conducting public programmes. In turn these people gave a kind of legitimacy to the organizations. Otherwise they might have gone the way of the NGOs in Bangladesh, or those NGOs who are now being attacked by the Maoists. So the voluntary organizations were a typical transitional fabric. They enabled the protest dynamics to continue. Other civil society efforts, e.g. Association for Protection of Democratic Rights (APDR) and human rights and civil liberties activists, were also part of that. ${ }^{9}$

Today we have a consciousness that is vaguely leftist, but it is not based on an ideology. There is an issue-based coming together. The human rights movement is like that. This culture emerged with the help of the voluntary organizations. A new culture of protest was being formed.

The power of the people of the city to be a nuisance to the rulers was not exhausted. It took only a decade-the eighties-to constitute itself again. Colleges, universities, voluntary organizations, new types of organizations-all these helped the culture of protest in Calcutta to survive. 

remain of course, but they are kept outside the city. And capital is extremely frightened here. the emergence of this new politics. the descent begins.

The agenda of global capital to restructure Kolkata-one really cannot say whether that can ever be successful. Paris, London, New York, Milan, even Bangkok-all were successfully restructured. In comparison to any Indian city, Bangkok witnessed massive transformation, with every kind of infrastructure being implanted. But today we find violent protests on the streets of Bangkok. Or look at Hyderabad-today we have Cyberabad, linked to the airport, bypassing the old city, and representing a new entity, in the context of the new global economy. Lewis Mumford has written about how the highways transformed New York, decimating the unruly Bronx. Labourers are the split soul of the city. Labour from the provincial hinterland builds the new city, like cyberabad. Where do they go after that? They either die, or become drunkards or prostitutes, or are a travelling army of labourers proceeding to build the next new city.

Today's city is not the city of the 1960s. The 'dirty things' of the city, like the shanties,

Hence we see, in the context of today's Kolkata, the ruthlessness and fury of Tata: the desire to restructure, and the anger at not being able to do so. Tata is, willy-nilly, having to deal with politics. He shouldn't have to do so. Whether one is a neo-classicist or an Adam Smithian economics-in the sense of the pursuit of happiness-is kept separate from politics. But now globalization is compelling corporate capital to engage in and control politics, and equally, politicians cozy-up to industrialists. But that is a kiss of death. Rulers need to leave a neutral space in which they can engage with the ruled, the independent space of politics. Rulers cannot afford to be partisans. They have to stand above or rise above partisan considerations. If politics and business mix then capital too loses a free ground to act in. So we had the wall around the car plant in Singur, which was built at the gunpoint of the state's police, under Section 144 (banning public assembly).

Politics has to embrace capital in order to modernize the city and make it governable.

How do you view left politics in Kolkata at the present juncture?

Left politics is dead in Kolkata. Something new is emerging, it is a social phenomenon, one could call it a new left if one wants. These twenty years, 1987-2007, were crucial for

Kolkata is still showing the way, even after its decimation. One must not underestimate this transition period, the last two decades. How would one explain the reservoir of protest that we see right now if everything was lost after 1977 ?

More philosophically, Bengal is still a pioneer, but so are Tamil Nadu and Kerala partly, although their imagination is still rural and governmental. Bengal is not anti-modern, but it is still the land that is producing counter-modernity, while engaging with modernity. William Carey, Rammohan Roy, Vidyasagar, Tagore-all accepted modernity but were still not content. Why? They were for modernity plus something.

Bengal was the first land to be colonized and modernized. Hence it has the most deep rooted appreciation, intellectual and spiritual, of what colonial modernity is all about, while of course retaining feudal features. Bengal continuously accepted this modernity but interrogated its inadequacies, never satisfied with the given version of modernity. There is an obsession with justice. 'Is it just? What are the yardsticks? Can it be better?' The CPI(M) did not understand this truth. The peak of a mountain is the point from where 


\section{How do you view the emergence of coercion to support the requirements of globalized} capitalism, for instance as witnessed in Singur or Nandigram?

Is primitive accumulation (i.e. extra-economic, coercive) a historic phase of the past? Or does each phase of capitalism revisit and repeat the story of its primitiveness? Globalization is supposedly the latest phase of capitalism, it is supposed to make Lenin outdated, and so on. But it is said that 'everything is surreal, nothing is concrete, except capital'. The real story of globalization is something else altogether. Actually, once again, non-capitalized terrain has to be 'primitively' acquired and brought to the fold of capital. Globalization revisits its own past, but in real time.

Tata has also undergone transformation. Their business is today global, and principally through acquisitions. And India is like a colony of this multinational. The metamorphosis of Tata has taken place at the same time as the spotlight was on Reliance. Reliance began with primitive accumulation, with skulduggery. Reliance clicked because it benefited from globalization. They possessed superior business skills, but they had also switched to the major new fields. Reliance is another classic story of business development. But Tata had begun as an investor, as an industry builder. For sure, they were exploiters. In fact, the Communist Party of India in Bihar was groomed in struggles against Tata. What new industry has that Tata taken up? It had to exit from many spheres (e.g. Haldia Petrochemicals, steel production in Bangladesh). But they have acquired companies internationally. Tata Motors has come to be more significant in the Tata group. The acquisition of Jaguar may be seen in that light. Tata is now like the old British managing agencies, with a foot in everything.

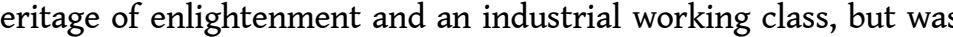
suffering from economic stagnation. It was encumbered with a backward economy in comparison to other parts of India. It had its crust of anglicized and westernized elite. The period of the 1980s and 1990s must be seen in such a context. Bengal was searching for a line. And that line comes, not with Narmada, but with Nandigram. Nandigram is a project that has been in the making for 20 years.

It is the fate of West Bengal and therefore the city of Kolkata primarily, to bear the mark of each stage of capital's growth in India. The struggles in Singur and Nandigram are necessarily against capital, while the Narmada struggle, despite everything else, is not so. Just like Kolkata had to bear the brunt of weavers' thumbs being cut (in the East India Company era), once again, today, Kolkata faces a similar situation. Because Bengal chooses to be resistant and recalcitrant.

\section{BIBLIOGRAPHY}

Banerjee, Sumanta (1980) In the Wake of Naxalbari, Kolkata: Subarnarekha. Bhattacharya, Debashis (2000) Sottorer Dinguli (Bengali, trs. The Days of the Seventies), Kolkata: Ekhon Bi-songbad. 
Mageli, Eldrid (2001) NGO Activism in Calcutta, 1973-1997: Exploring Unnayan, PhD thesis, University of Oslo.

Mallick, Ross (1999) 'Refugee Resettlement in Forest Reserves: West Bengal Policy Reversal and the Marichjhapi Massacre', The Journal of Asian Studies, 58(1), February, pp. 104-125.

Samaddar, Ranabir (2008) Prescribed, Tolerated \& Forbidden Forms of Claim Making, Monograph, Calcutta Research Group, Kolkata.

\section{NOTES}

1. This interview took place in Kolkata in October 2008, as part of a project commissioned by the Centre de Sciences Humaines, New Delhi, to compile a series of activist narratives on urban protest in Kolkata over the two-decade period, 1987-2007. This was a contribution to an international research project on participation in urban governance in Indian and South African cities.

2. The latest elections to the West Bengal legislative assembly took place in May 2011. It was a hard fought election campaign, with Mamata Banerjee's Trinamool Congress showing great confidence, and the Left Front claiming that support for it had finally picked up after the series of electoral reverses. As it turned out, the Left Front led by the CPI(M) was defeated and the electoral alliance of the Trinamool Congress and the Congress obtained a landslide victory. The extent of the disaffection against the CPI(M) led Left Front surprised even their opponents. Mamata Banerjee was sworn in as Chief Minister in West Bengal, ending 34 uninterrupted years of rule by the Left Front, and thus beginning a new chapter in the story of West Bengal.

3. The naxalite movement takes its name from Naxalbari, a place in the northern part of the state of West Bengal in India. An uprising of peasants took place here in 1967 following police firing on a group of villagers demanding their right to the crops on a piece of land (see Banerjee 1980, Bhattacharya 2000). In 1969, members of the left wing of the Communist Party of India (Marxist) established the Communist Party of India (Marxist-Leninist), and saw Naxalbari as a spark that would ignite the revolution in India. Peasants were urged to seize lands and kill landlords. Students in some colleges in Kolkata were inspired to join the movement, and they went to villages, especially in tribal areas, to exhort and mobilize peasants to seize and cultivate land and form liberated zones. The movement also spread to the city of Kolkata, with robberies and killing of policemen to collect money and arms. As the state eventually reacted with bloody fury, the movement rapidly degenerated into blind violence and killings to settle political scores, in turn leading to tit-for-tat violence. By the mid-1970s, the naxalite uprising had been all but crushed, with a number of factions and party and political formations. But it also spread to other parts of India, such as Bihar, Andhra Pradesh, Maharashtra and Madhya Pradesh, adopting new positions and strategies in each place. The current Maoist insurgency in different parts of India may also be seen as another derivative of this process.

4. Refugees from erstwhile East Pakistan had returned to West Bengal from their resettlement site in the state of Madhya Pradesh, on the encouragement of a minister from West Bengal. They settled in Marichjhapi in the deltaic Sunderban region. The CPI(M) led Left Front government enforced a blockade in the area and in subsequent police firing about 15 people were killed according to the official report. However, the refugees themselves claimed that thousands had actually perished during the police firings as well as from starvation during the blockade. See Mallick (1999).

5. See Heuzé in this issue. 
6. Political opponents of the CPI(M) as well as commentators have emphasized the brutally violent methods used by the CPI(M) to establish their domination. But Samaddar does not touch upon this in this interview.

7. The period from the late-1970s saw the emergence of 'voluntary organizations', or activist, non-profit organizations, often established by one or a group of well-educated, urban professionals, engaged in rural and grassroots interventions and espousing community awareness, action and empowerment. Some of these organizations subsequently went on to become large, well-endowed institutions. PRIA (Participatory Research in Asia) and CSE (Centre for Science and Environment), both based in Delhi are examples of the latter trend. Samaddar contrasts these with voluntary organizations in Kolkata, like Unnayan, which remained small but engaged intensively in the local situation and activities.

8. Unnayan was an activist group in Kolkata that was active in the late 1970s and through the 1980s, campaigning for the rights of the city's labouring poor, including rickshaw pullers and squatters. VHAI was an all-India organization campaigning for 'Health for All'. Its West Bengal unit had a more activist and political slant (see Mageli 2001).

9. APDR, established in the early 1970s to campaign for release of political prisoners of MarxistLeninist persuasion, is one of India's oldest civil liberties and human rights organizations. It is active in campaigning against custodial deaths.

\section{ABSTRACTS}

A political scientist and thinker talks about protest movements in his city, Kolkata, during the period from the late 1980s. The CPI(M)-led Left Front was elected to government in the state of West Bengal without interruption from 1977. It wielded enormous power over society. The turnaround finally came in 2007, with a wave of protest agitations that eventually allowed the opposition politician, Mamata Banerjee, to lead her party to electoral victory in 2011. At the time of the interview, in 2008, Samaddar talks about the 'Mamata phenomenon', locating the roots of her populist politics in the protest stream of the 1980s and 1990s. This period saw protest attempting to find its feet once again in the now blighted city. Samaddar points to the emergence of a new politics in the wake of the death of the old left politics. The conversation with Ranabir Samaddar helps one to better understand the political transformation in West Bengal, and also throws light on a way of thinking and a praxis whose roots lie in the robust civic and political life of that state.

\section{INDEX}

Keywords: CPI(M), Kolkata, Mamata Banerjee, protest, West Bengal

\section{AUTHOR}

\section{RAMASWAMY}

An independent scholar 